\title{
ORE MINERALS FROM THE LAMPROITE GROUND MASS.
}

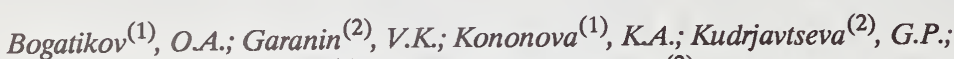 \\ Makhotkin $^{(1)}$ I.L. and Mikhailichenko ${ }^{(2)}, O . A$.
}

(1) Institute of Geology, Geochemistry and Mineralogy Ore Deposits, Academy Sciences of USSR, 109017, Staromonetni per., 35, Moscow, USSR; (2) Geological Department of Moscow State University, 119899, Lenin's Hills, Moscow, USSR.

The study or mineralogy of oxides from the lamproite ground mass of different regions (Austxalid, Spain, IJSSR) and magnetic properties of these rocks has allowed to lefine treir typomorphism at the level of provinces, types of lamproile rocks (ultrabasia, basic) and their facies belonging (tuffi, tuffbreccia, intrusive lamproites, dyke fasies ). It is shuwn that the typurarphisu of the coriposition of minerals from the ground mass of lamproites and Lheir sproding correlates tu the lamproite diamond bearing. The spreading of mi:roirystal oxides ("density" of ore milleralizatjur), hle set of different mineral phases and their correlation, the size uf the extract.s and thrIr chemical and phast romposition rarer l.t the typomorphic feeatures of oxides from the ground mass of lamproites.

In a nutshell, the essence of the discovered typomorphism is the following. As far as it: detallis at. the province level

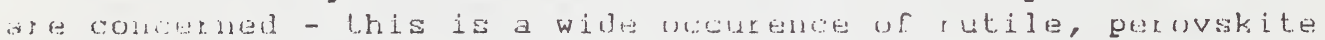
ard K-Ba containing titanates jn the ground rias or lamproites of Austialia; apulite and ilmenite fur lyke rocks of Spain aru 1. Larufagnelite (magnetite) sproificatiun uf Aldan Shield lampwiles. Il should be alsu rutel that there is the degredse of :hrome: and ragresian content of the iniarougstallid mineraliza-

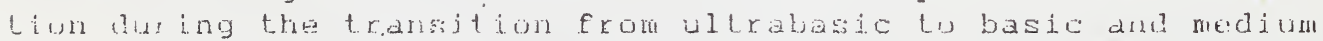
(from olivine to ghlogopite, leboite, linpside and eta. lamproitas) and the increase in the same alrection of it.s titanilum and, especially, iron content. Speaking about the racies belonging of lamproites it should be noted that there. is a wile spreading (to one order and more) of microiryataljice oxides in the rocks of dyke racies as comparea with the dialreras one and, parallelly tu it, its structure is more coarse grained. The similar difrertrot is observed between intrusive dud tuff (or brecial facies, lut at somewhat lower level.

Taking into account the impor lance of microcrystallic extraftjurs in the ground mass of spinels as ruse atreitive jneli-

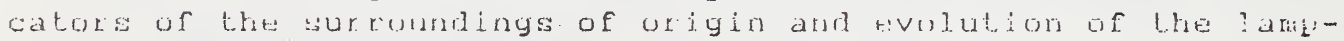
roite magma, we'll consider in more details the aralysis or the typumoribic puculiarities of spinels. Tre most character.stic whe is: the following : the prevailing (or wide) luvelopment, anong mierocrystali coxides, of high magnesian type of chromite in the ground mass of rich and diamond beariny rocks dra their mainly homogeneous form of extractions. With the deareasit of the rock diamond bearing, the homogeneous grains wf chrome spinellides are changed into zonal extractions. with chrome maynetite borders.

The range of spinellide of non-diamond bearing rocks is characterised by the alearly marked domillation of the zonal chromite-chrome magnetite extractions over homogeneous chromite ore and domination of homogeneous chrome magnetite and titanomagnetite differences. This tendency unanimousiy illustateg the direct link between the depth and oxide potential of the 
developing lamproite system, on the one hand, and its diamond bearing, on the other hand.

On the basis of the magnetic data some peculiarities of ferrimagnetics reflecting the conditions of their formation can be discovered. In particular, for lamproites, containing zonal grains of chrome spinels, the curves $I_{\text {sis }}(T)$ in the heating cooling cycle are irreversible.Depending on the composition of the zones both the increase magnetization of $I_{j}$ saturation and Curie To temperature (olivine - chrome spinellide) and the decrease of these parameters (chrome spineliide - magnetite) can take place.Chrome spinellides with the high content of chrome on the $I_{i j}(T)$ curve in the $T<T_{0}$ field have a sharp decrease of Is while $T$ is increased. The $I_{\text {sis }}$ increasing in result of the thermo treating indicates the formation of ferrimagnetic phase with the high content of magnetite minal (transformations pyrrhotine - magnetite, titanomagnetite - magnetite and ilmenite lamellae and others). In its turn, zonality and the titanomaghemitization process show the conditions for less probable preservation of diamond. The availability of high chrome content, vice versa, proves the depth conditions of the lamproite formation. High content of titanomagnetite and magnetite proving the oxidation processes shows the unfavourable conditions for the diamond formation. It is reflected in high valuea of magnetic susceptibility $\mathscr{X}_{0}$, magnetizations $I_{m}, I_{m,} I_{m i s}$ and the values of temperatures Curie $\mathrm{T}_{\mathrm{c}} \approx 580^{\circ} \mathrm{C}$.

Thus, the study of oxides from the ground mass is the effective way to carry out the passportization of the lamproite bodies and their diamond bearing evaluation. 